\title{
The Archaeological Map for the Reconstruction of the Ancient Topography of the Greek and Roman City of Taormina
}

\author{
Lorenzo Campagna \\ University of Messina, Department of Ancient and Modern Cultures, Messina \\ email: lorenzo.campagna@unime.it
}

\section{Giuseppe Scardozzi}

National Research Council of Italy - Institute for Archaeological and Monumental Heritage, Lecce email: g.scardozzi@ibam.cnr.it

\begin{abstract}
TResearch is aimed at the production of a tool that could be useful both for the reconstruction of the ancient urban planning and its development during the Greek, Roman and Medieval ages, and for the management and preservation of the archaeological heritage of Taormina; in fact, the new archaeological map could be included in policies aimed at an urban development that respects the existing ancient remains and promotes their enhancement of value.

The paper concerns the research project started in 2009 and aimed at the production of the archaeological map of Tauromenion/Tauromenium, on which the modern Taormina lies. The project is carried out by the Department of Ancient and Modern Cultures of the University of Messina and the Institute for Archaeological and Monumental Heritage of the Italian National Research Council, with the cooperation of the Archaeological Superintendence of the Province of Messina and the Archaeological Park of Giardini Naxos.

The research project involves a context characterised by a long continuity of life during centuries and it is based on:

1) archaeological and topographical surveys using a differential GPS system and a total station;

2) systematic study and analysis of archival documentation, previous bibliographies and historical cartographies;

3) interpretation of aerial photos, in particular
\end{abstract}

those taken between the years 1920s and 1940s, when some sectors of the ancient city and necropolises were not still covered by the extension of the modern town.

All the collected data were georeferenced in a digital archaeological map, where all the ancient monuments and structures, both still visible and those re-buried after small-scale excavations, are integrated on a up-to-date large-scale vector cartography. The map is integrated in a web-oriented GIS platform developed using open source software and cloud computing solutions; it is aimed at the data management and sharing between the different institutions involved in the project.

Therefore, the research is aimed at the production of a tool that could be useful both for the reconstruction of the ancient urban planning and its development during the Greek, Roman and Medieval ages, and for the management and preservation of the archaeological heritage of Taormina; in fact, the new archaeological map could be included in policies aimed at an urban development that respects the existing ancient remains and promotes their enhancement of value.

Keywords: Archaeological map; Taormina; Hellenistic and Roman urbanism; WebGIS; Preservation. 


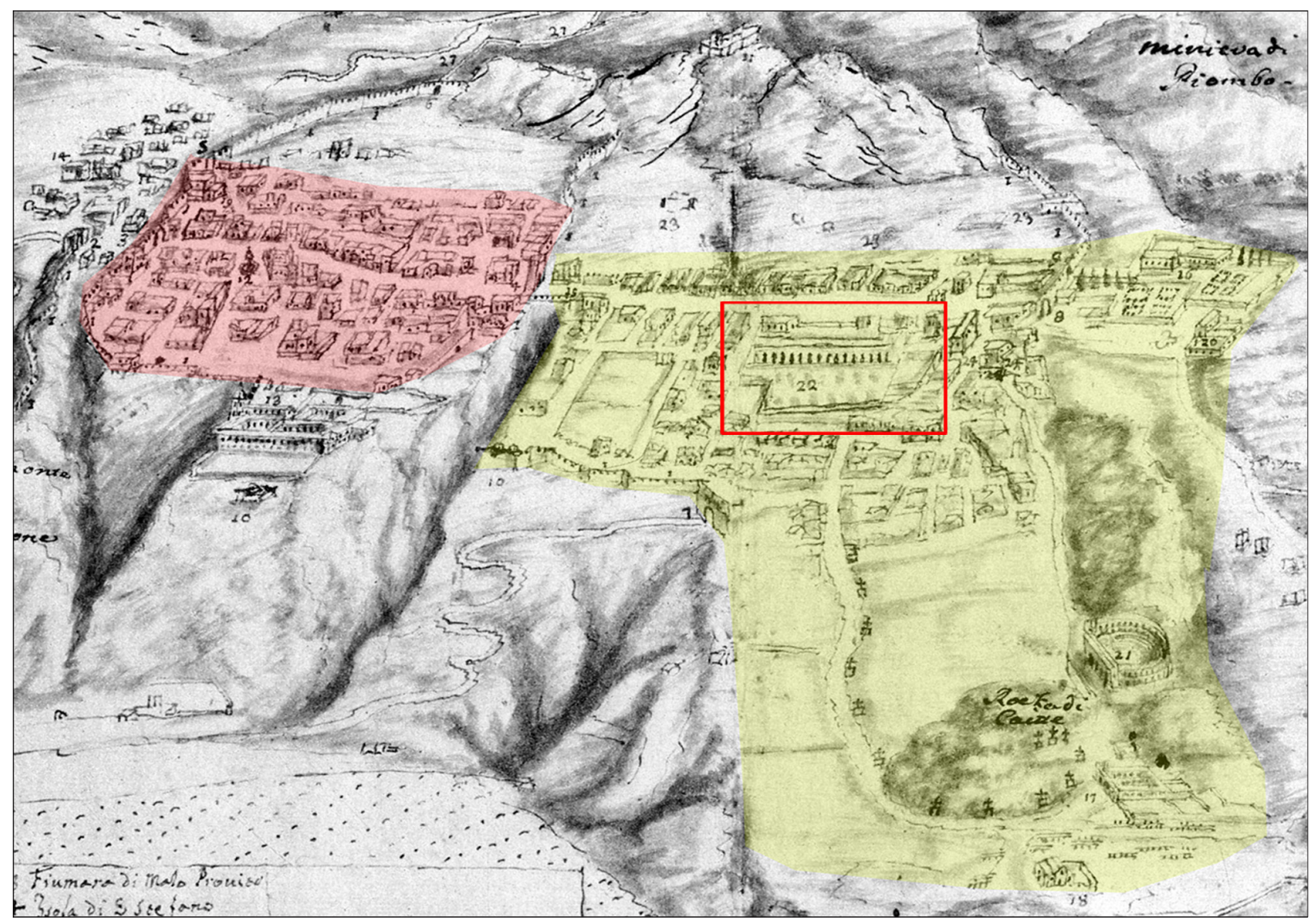

Fig. 1. Detail of the Pianta e veduta della Notabile e Fedele Città di Tauormina (beginning of eighteenth century): in pink the Medieval city, in yellow the area of the extension starting from the Late Medieval Age. The red rectangle highlights the area of Naumachia and Giardinazzo (Dufour, 1992: fig. 193).

\section{Introduction: the Taormina research pro- ject}

Since 2009 the Department of Ancient and Modern Cultures of the University of Messina and the Institute for Archaeological and Monumental Heritage of the Italian National Research Council in Lecce (IBAM-CNR) carried out a research project aimed at the reconstruction of the ancient urban layout of the Greek and Roman city of Taormina, along the eastern coast of Sicily. The research is also performed with the cooperation of the Archaeological Superintendence of the Province of Messina and the Archaeological Park of Giardini Naxos.

The research project concerns the study of the ancient topography of a settlement characterised by its continuity of occupation since ancient times, with a view to the conservation, management and appropriate use of cultural heritage. In particular, the project is aimed at the production of a largescale digital archaeological map of the site, which integrates all the ancient remains of Tauromenion/ Tauromenium. These include both the monuments that were always visible over the centuries or unearthed in the nineteenth and 20th centuries and the structures discovered in the last six decades during the expansion of the modern city and public and private building works. First of all, this archaeological map will be an important tool for the study of the urban planning of the Hellenistic city and its transformation during the Roman period and the Middle Ages. The map, integrated in a webGIS platform, will also play an important role in the planning of policies to guarantee the conser- 


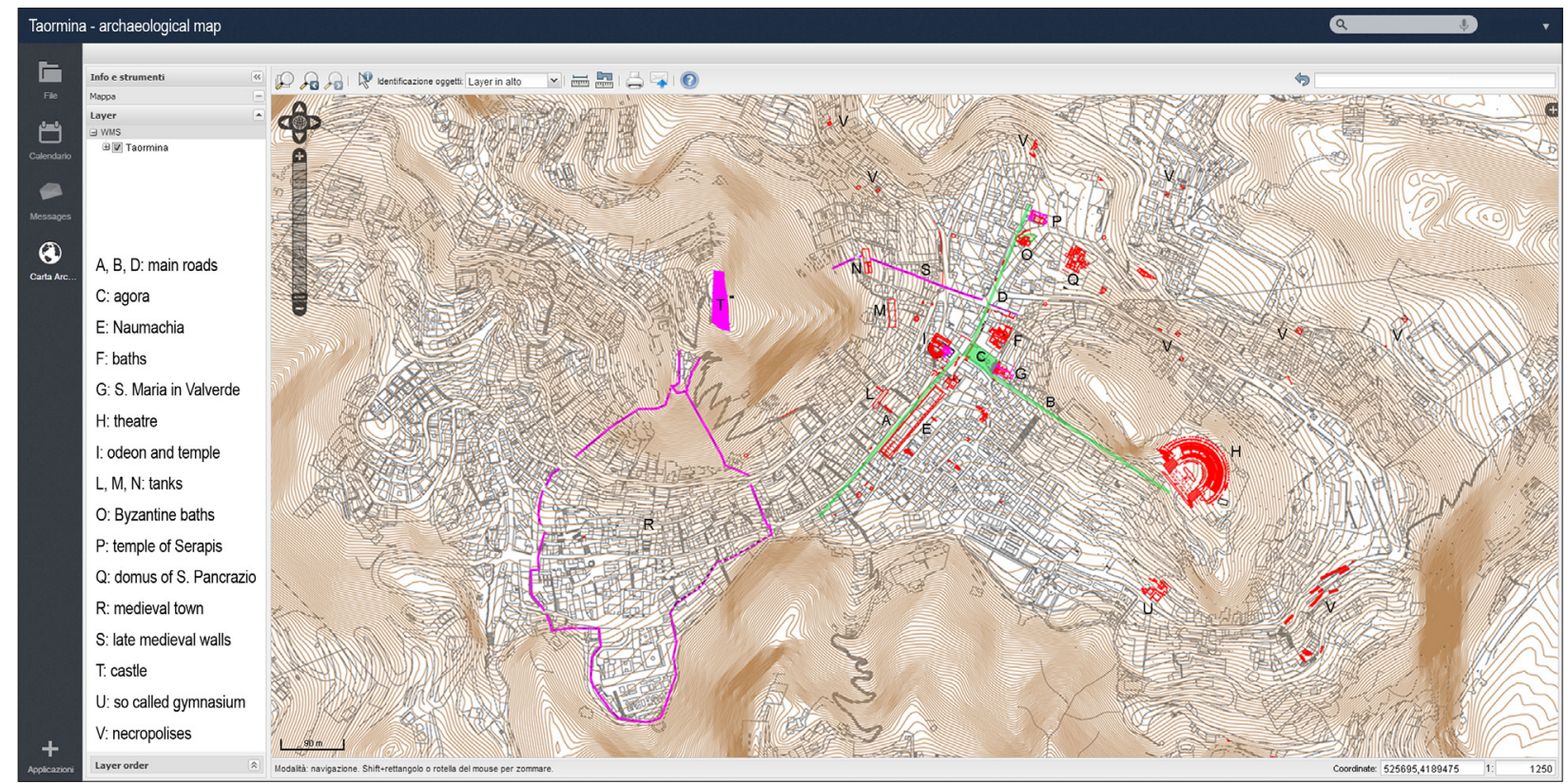

Fig. 2. The archaeological map of Taormina.

vation of the monuments, as part of a wider plan for sustainable urban development that respects the existing archaeological heritage. This heritage needs to be protected and made accessible to the public, again considering that the city constitutes an important destination for international tourism. Today only the famous theatre, with its spectacular views over the Ionian Sea and towards Giardini Naxos and Etna, is visited by tourists, while the other monuments lie practically abandoned. Moreover, there is not an archaeological museum to document and showcase the city's thousands of years of history. Therefore, the research project is aimed to increase the knowledge of the historical development of Taormina but also to produce an instrument for the management and preservation of its archaeological heritage.

\section{The Ancient City Planning of Taormina: State of Knowledge, Questions and Per- spectives of Research}

Taormina (from the Greek Tauromenion, Latin Tauromenium) was founded around the middle of the fourth century BC, occupying the natural terraces that lie, with various orientations, on the slopes of the hill known as Monte Tauro. The settlement was built around the two heights on which the castle and the theatre still stand, at an altitude of between m 180 and 220 AMSL, close to the Ionian coast (Battistoni \& Gulletta, 2011; Campagna, 2009; Lentini, 2005). The city was initially under the control of Syracuse, but in the last few decades of the third century BC, it became part of the Province of Sicily as a civitas foederata of Rome. In the early Augustan Age a colony of Roman citizens was founded there. Under the Byzantines it became an important strategic centre, as it was an obligatory staging post for communications between Messina and Catania along the coast. At the beginning of the tenth century $A D$, it was conquered by the Arabs, who destroyed it. It was then rebuilt on the terrace immediately below the castle, where the oldest part of the modern city lies today, at the extreme south-western end of the Hellenistic-Roman settlement, the ruins of which lay outside the new city walls loutside the gate known as Porta di Mezzol. Following the Norman Conquest in 1079 , in the twelfth century the town expanded into the areas lying North-east of the Early-Medieval city, on the site of the Hellenistic-Roman settlement. In the following centuries, when Taormina became 
part of the Kingdom of the Two Sicilies, the area of the ancient Tauromenion was delimited by a circuit of walls and was progressively urbanised (fig. 1), up until the present day.

In Taormina many monumental remains from both the Hellenistic and Roman Imperial periods are preserved or were found during excavations. Some monuments remained visible over the centuries, such as the Hellenistic theatre, rebuilt in the Roman Imperial period, or the monumental complex of the Roman Imperial period known as Naumachia, or again the temple of Serapis, from the Hellenistic Age and incorporated in the Church of San Pancrazio. Other monuments came to light during the archaeological excavations carried out as a result of building works, both at the end of the nineteenth century (such as the odeon from the Roman Imperial period and the nearby Hellenistic temple incorporated into the Church of Santa Caterinal and in the 1960s and 1970s, during the transformation of the city as a result of its urban development. The latter discoveries include the Hellenistic building known as bouleuterion and the baths of the Roman Imperial period in the area of the Zecca, the so called Gymnasium (probably a private residence) on the south-western slopes of the hill of the theatre, the large urban domus of Villa San Pancrazio on the slope facing Monte Tauro, and the structures unearthed below the Palace of Congresses, which was built over the Medieval Church of Santa Maria in Valverde.

There is a long tradition of archaeological studies about Taormina, but these are essentially focused on individual monuments, such as the theatre. Only in the last few years has attention turned to the analysis of the Hellenistic and Roman town planning but many reconstructions of the urban layout are based on schematic maps that are not complete and detailed. So, it has become clear that this field of research requires a large-scale archaeological map showing the precise position of all the ancient remains, which is the first aim of the present research project.

L.C.

\section{The New Archaeological Map: Methods and Aims}

The previous reconstructions of the urban layout does not document the relationship between the ancient urban planning and the specific morphology of the site. On the contrary, the reconstruction of the Greek-Roman urban layout of Taormina and its transformations over centuries needs a largescale archaeological map documenting the precise location of all the known ancient remains, in terms of both planimetric and elevation position, due to the particular morphology of the site (Castrianni et al, 2008). In fact, the archaeological research on Taormina has always been missing a detailed map in which all the known archaeological items are accurately positioned and their interrelationships are clear. Therefore, the first aim of the project was the production of a digital large-scale archaeological map showing the exact positioning of all the known ancient evidence, from the remains of monuments to sporadic structures and materials, whether still visible or no longer conserved; this work allowed the integration in a single homogeneous container (i.e. the map) a large collection of extremely fragmentary data, whose interrelationships were effectively obscured by the urban fabric of the modern city. Therefore, it facilitated observations of the ancient urban planning of the city, highlighting connections between apparently unrelated archaeological remains and thus acquiring new data on the ancient topography of Taormina. As base map, an aerophotogrammetric restitution at 1:2,000 scale (contour lines with 2 $\mathrm{m}$ interval) was used. It is sufficiently up-to-date (it was produced in 2000s) and in vector format, requiring only few edits (such as the gathering of data into new, homogeneous and logical layers) and additions in order to adapt it for the specific needs of the archaeological research.

The modern Taormina completely overlays the ancient city and large areas of its necropolises. So, the recent work is mainly based on the systematic study of previous bibliography and collection of the archival documentation, in many cases unpublished. In particular, all the structures 


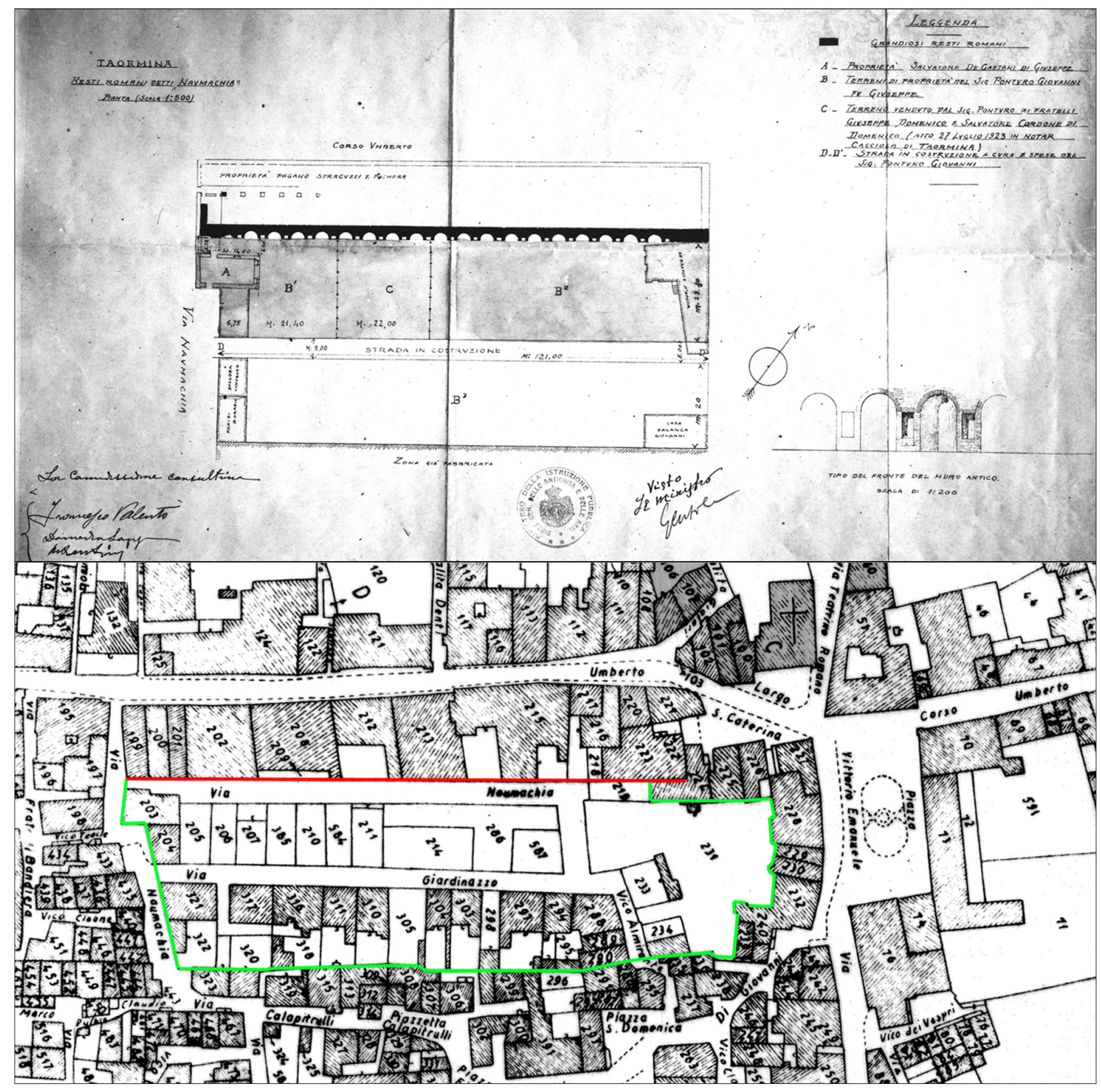

Fig. 3. On top, map from the property register's office of the Naumachia façade and the Giardinazzo area which is still not completely urbanised (1923-1924; Rome,

Fototeca Nazionale); On the bottom, map from the property register's office (1930s), green line indicates the hypothetical perimeter of the Giardinazzo area (still not completely urbanised), red line highlights the façade of the Naumachia.

unearthed by the Archaeological Superintendence of the Province of Messina, generally by means of small-scale excavations performed in the last 60 years during public and private building works, were georeferenced in the archaeological map; in many cases they consist of fragments of walls, which nevertheless acquire greater significance when integrated into the overall frame. Archaeological and topographical surveys were performed in the ancient urban area and surrounding necropolises, also using a high-precision differential GPS system and a total station. A specific archaeological field-walking also focused on the ancient 


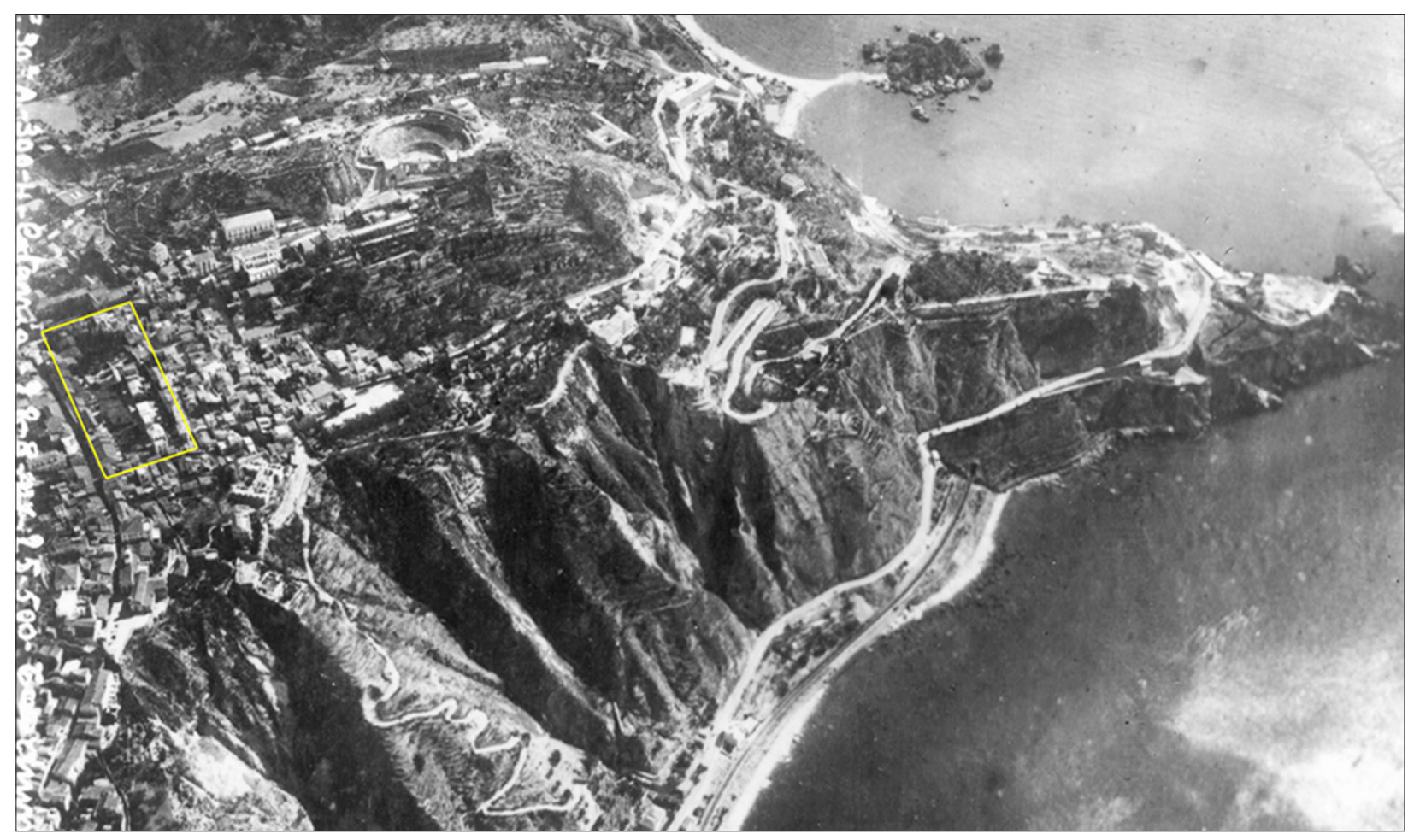

Fig. 4. Aerial photo of Regia Aeronautica taken in 1927: the Giardinazzo area (yellow rectangle) is still partially not urbanised (Rome, Aerofototeca Nazionale).

aqueducts of Taormina, of which the remains were documented and the routes were reconstructed; they brought drinking water to the various cisterns built on the terraces along the eastern slope of Monte Tauro. Furthermore, very important data were acquired from the historical cartographies (in particular from the sixteenth to the first half of the 20th centuryl and the aerial photos taken between the years 1920s and 1940s. Of particular interest are the aerial photos taken by the Regia Aeronautica loblique images taken in 28 August 1927 and 28 May 1930, preserved in the Aerofototeca Nazionale in Rome), the Istituto Geografico Militare lvertical images taken in 24 May 1943 and 19 October 1954, preserved in the IGM archives in Florence) and Royal Air Force (vertical images taken in 25 June 1943 and 5 July 1943, preserved in the Aerial Reconnaissance Archives of the Royal Commission of Ancient and Historical Monuments of Scotland, in Edinburgh). In fact, this documentation shows some areas of the ancient city and sur-

rounding necropolises before they were covered by the extension of the modern town in the last 60 years.

All the collected data were georeferenced in the digital archaeological map, which allows the acquisition of new information for the reconstruction of the ancient topography of Tauromenion/ Tauromenium, particularly thanks to the integration and correlation of the fragmentary ancient remains. The precise 3D location of the collected data on a detailed vector base-map highlights, in many cases, the strict integration of the ancient urban planning to the morphology of the site. Thus characteristics of the ancient city may also be documented thanks to the georeferensiation of the archaeological features on a Digital Terrain Model produced using spot elevations and contour lines from the vector base map.

Furthermore, the digital archaeological map is integrated in a web-oriented GIS platform developed using open source software, with the aim of data management and integration; the need of data sharing and contemporaneous implementation of databases from the various involved institutions suggested the use of cloud computing solu- 


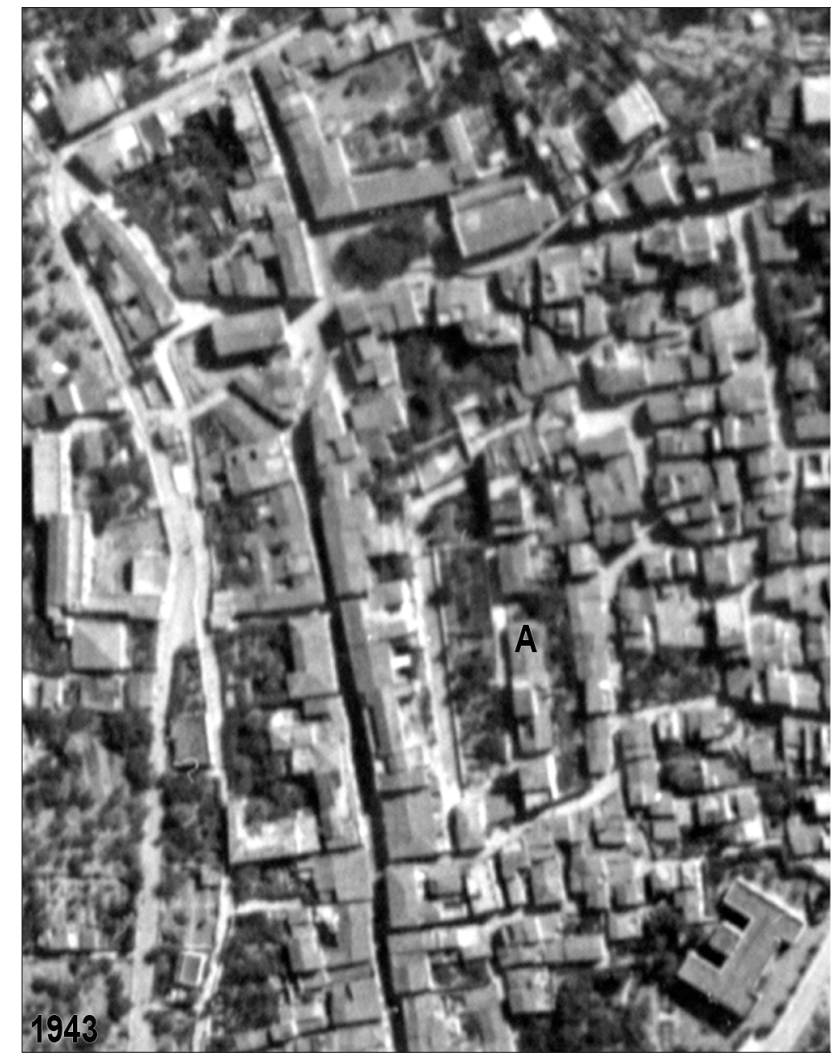

Fig. 5. The Giardinazzo area (A) in a RAF aerial photo taken in 1943 (left) and in an IGM aerial photo taken in 1966 (right), when it was almost completely urbanised (Rome, Aerofototeca Nazionale).

tions for the GIS platform (Di Giacomo \& Scardozzi, 2014). The aim is the production of a tool that would be important not only for the archaeological research but also for the preservation and management of the ancient remains and monuments. In fact, the urban expansion of Taormina in the last decades has not always taken sufficient account of the ancient remains and a tool (such as an archaeological map) designed to support the correct planning of the urban growth and modernisation of utility networks, in which the ancient remains were precisely located, was completely lacking. So, the new vector archaeological map would be available for the Archaeological Superintendence and the local Municipality, becoming part of a wider plan for a sustainable urban development that respects the existing ancient remains and for policies aimed

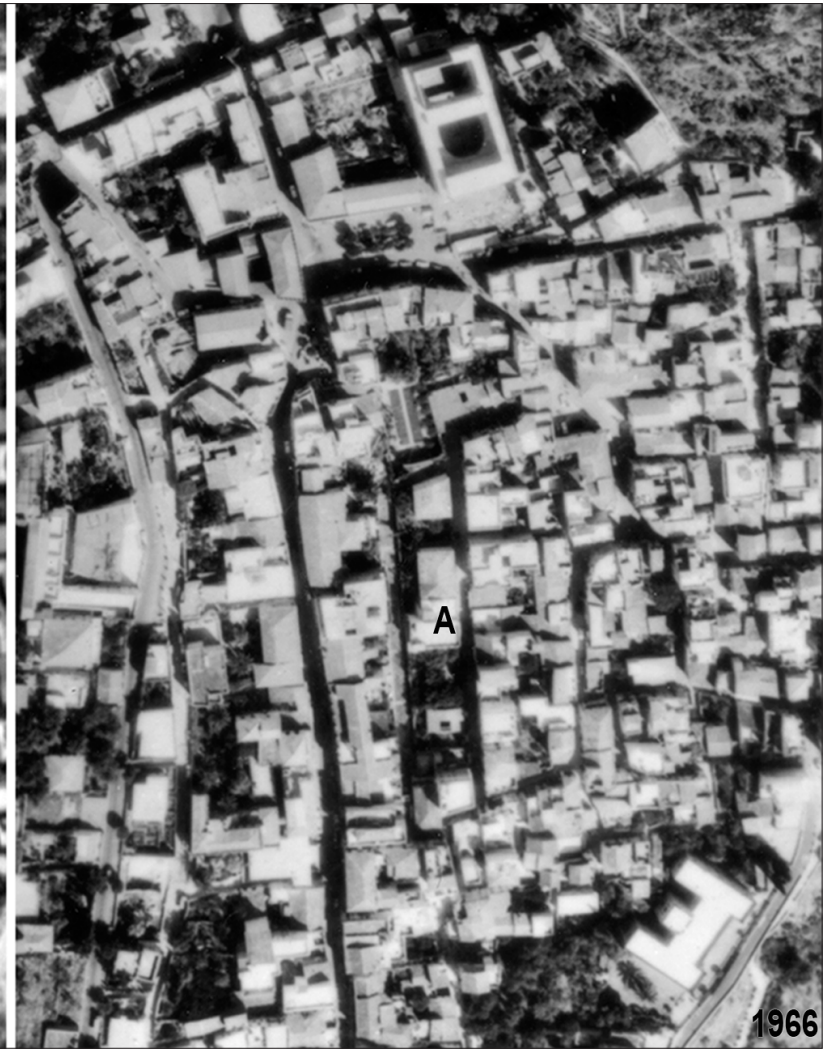

at the enhancement of value of the archaeological heritage in Taormina.

\section{Some preliminary remarks on the ancient topography of Taormina}

The research, still in progress, has already achieved some interesting results in the reconstruction of the ancient topography of the city and its necropolises. It seems clear that the Hellenistic Tauromenion had a regular urban layout in which the various sectors of the city were integrated to the orientation and altimetry of the different natural terraces where they lay (Campagna, 2009). In general, the main axes of the urban plan, that was maintained with some renovation also in Roman times, can be identified in two roads, not perfectly orthogonal and approximately corresponding to the modern Corso Umberto I and Via del Teatro Greco (fig. 2, A-B); the first road, at least $300 \mathrm{~m}$ long and with a SW-NE orientation, ran across the terrace down Monte Tauro, while the second, at least $360 \mathrm{~m}$ long and with a SE-NW orientation, 
went through the terrace where at the west end the theatre was built. In the area south-east of the corner between the two roads there is the modern Piazza Vittorio Emanuele II (fig. 2, C) traditionally identified with the Greek agora and the forum of the Late Republic period and the Imperial Age. From Piazza Vittorio Emanuele II, a third road (fig. 2 , D), not orthogonal to the two mentioned above, continued in a north-east direction (today partially followed by Corso Umberto I) for about $230 \mathrm{~m}$ and arrived at the area of the Hellenistic temple of Serapis, today included in the Church of San Pancrazio, built in the seventeenth century AD.

A Hellenistic temple was to the north-west of the agora. Immediately to the west of this monument, an odeon that reused the temple such as a scaena was built in the Roman Imperial Age; in the seventeenth century $A D$, the Church of Santa Caterina was partially built on the remains of the two buildings. On the east of the agora were the baths, built in the Imperial period on a Hellenistic building identified with the bouleuterion or the gymnasium; other structures closed the square along the southern side and they were incorporated in the Church of Santa Maria in Valverde. The layout of the area immediately to the west of the agora is still uncertain; it is possible to suppose that this area was organised in different levels descending to the square in front of the so called Naumachia, that was built about 5-6 m lower than the plane of agora. The Naumachia is a monumental building with a rectangular plan (120 m long, $18 \mathrm{~m}$ wide) sited along the south-western side of Corso Umberto I, at a lower level; it was built in the Roman Imperial Age on a Hellenistic stoà and was almost partially used as a tank (Campagna \& La Torre, 2008). The building also functioned as a containing wall for the terrace above, about $5 \mathrm{~m}$ higher up, on which ran the already mentioned ancient road corresponding to the modern-day Corso Umberto I. It had a brick façade with niches, in front of which there was a large rectangular square, corresponding to the so called Giardinazzo area, an open space occupied by a garden and still partially preserved until the 1920s; this area is nowadays quite all urbanised, but it was documented by his- torical cartographies of he sixteenth century lfor example see Dufour, 1992: fig. 193; see also above fig. 1) and old aerial photos. Two maps belonging to the office of the property register, dated 19231924 and 1930s (fig. 3), show the Giardinazzo area labout $48.5 \mathrm{~m}$ large along the north-west/southeast axis) before it was completely built over, while the aerial photos taken in 1927 (fig. 4), 1930 and 1943 (fig. 5, left) show its progressive urbanisation which after the First World War was limited to the south-eastern half of the area and it was completed after the Second World War (fig. 5, right). The second map (fig. 3, down) documents the Giardinazzo area extended in a north-eastern direction for a further $m 43$ circa beyond the façade of the Naumachia, almost as far as Piazza Vittorio Emanuele II, suggesting a possible direct link between the two piazzas. So, it is possible to suppose that the ancient square corresponding to the so called Giardinazzo area was elongated with a SW-NE axis in direction of the agora and with this second open area probably constituted a large public space arranged in two or more levels, maybe with different functions.

Lastly, it is interesting to highlight that the vertical old aerial photos, in particular those taken by RAF in 1943, which have a medium-to-large scale, also clearly show the regular urban planning of the area known as Piano Bagnoli, located immediately to the south-east of the Naumachia. This arrangement of the area probably reflects that of the Hellenistic-Roman city. The photographs, taken before the transformations of the second half of the 20th century and the insertion of new buildings that hamper the reading of the urban network, confirm the hypothesis that here the urban layout included a system of artificial terraces, which served to impose regularity on the two slopes that characterise the area (Campagna, 2009): the first one descends Corso Umberto I in south-east direction and its first terrace was occupied by the Naumachia and the piazza in front of it; the second one, steeper slope, descends from north-east to south-west, and corresponds to the southern slopes of the hill of the theatre.

These are only some preliminary remarks 
on the ancient topography of Taormina that are possible thanks to the new large-scale digital archaeological map. The forthcoming publication of this systematic work would be available to scholars and administration a useful tool for the reconstruction of the historical development of the urban planning of the city from the Hellenistic period to the Middle Age and for the management and preservation of the archaeological heritage of Taormina.

G.S.

\section{Acknowledgements}

On the Taormina archaeological map project researchers from various involved institutions work, among which it is important to mention Prof. Gioacchino Francesco La Torre (University of Messina), Dr. Mariagrazia Vanaria (Superintendence of the Province of Messina), Drs. Laura Castrianni, Imma Ditaranto and Giacomo Di Giacomo (IBAMCNR); Dr Di Giacomo, in particular, is working at the development and implementation of the webGIS of Taormina within a doctoral program at the University of Messina. Many thanks also go to Dr. Alessio Toscano Raffa (University of Messina), for cooperation during the archaeological and topographical surveys, and Dr. Gabriella Tigano (Superintendence of the Province of Messina) and Dr. Maria Costanza Lentini (Archaeological Park of Giardini Naxos) for their support to the research project.

\section{References}

Battistoni F \& MI Gulletta 2011: Taormina, in Bibliografia topografica della colonizzazione greca in Italia e nelle isole tirreniche, vol. 20, Siti: Sutera-Toppo Daguzzo: 42-112. Scuola Normale Superiore, Pisa/ Ecole française de Rome, Rome/Centre J. Berard, Naples.

Di Giacomo G \& G Scardozzi 2014: GIS cloud per l'archeologia. Strumenti open source per la gestione e condivisione dei dati, Archeologia e Calcolatori, 25, 93-112.

Campagna L, 2009: Urbanistica dei centri siciliani d'altura in età ellenistica: il caso di Tauromenion, in Congiu M, Miccichè C \& Modeo S (ed.), Eis Akra. Insediamenti d'altura in Sicilia dalla Preistoria al III sec. a.C. Atti del V convegno di studi, Caltanissetta 2008: 205-26. S. Sciascia Editore, Caltanissetta.

Campagna L \& GF La Torre 2008: Ricerche sui monumenti e sulla topografia di Tauromenion: una stoà ellenistica nell'area della Naumachia, Sicilia Antiqua, 5, 115-46.

Castrianni L, G Di Giacomo, I Ditaranto \& G Scardozzi 2010: Archaeological maps of ancient urban settlements characterised by continuity of occupation: A tool for historical research and protection of cultural heritage, in Proceedings of the Fifteenth International Conference on "Cultural Heritage and New Technologies" (Vienna 2010), City Hall, Vienna, 187-213.

Dufour L, 1992: Atlante storico della Sicilia. Le città costiere nella cartografia manoscritta 1500-1823, Arnaldo Lombardi Editore, Palermo.

Lentini MC, 2005: Tauromenion, in Ghedini F, Bonetto J, Ghiotto AF \& Rinaldi F (ed.), Lo stretto di Messina nell'antichità: 313-31. Edizioni Quasar, Rome. 
